\title{
The association of thyroid disorders with abnormal uterine bleeding
}

\author{
Prasad Yeshwant Deshmukh ${ }^{1}$, B. G. Boricha ${ }^{1}$, Ankita Pandey ${ }^{2}$ \\ ${ }^{1}$ Department of Obstetrics \& Gynaecology, MGM Medical College, Kalamboli, Navi Mumbai, Maharashtra, India \\ ${ }^{2}$ Department of Obstetrics \& Gynaecology, NRS Medical College, Kolkata, West Bengal, India
}

Received: 19 March 2015

Revised: 20 March 2015

Accepted: 18 April 2015

\section{*Correspondence: \\ Dr. Prasad Yeshwant Deshmukh, \\ E-mail: drpydeshmukh@gmail.com}

Copyright: $\odot$ the author(s), publisher and licensee Medip Academy. This is an open-access article distributed under the terms of the Creative Commons Attribution Non-Commercial License, which permits unrestricted non-commercial use, distribution, and reproduction in any medium, provided the original work is properly cited.

\begin{abstract}
Background: Dysfunctional uterine bleeding is an abnormal bleeding from the uterus in absence of organic disease of genital tract and demonstrable extragenital cause. Thyroid dysfunction is marked by large number of menstrual aberrations. This study is aimed at detecting thyroid dysfunction in patients with provisional diagnosis of AUB and refers positive cases to physician for further evaluation.

Methods: 100 cases of clinically diagnosed AUB were taken from Gynaecology OPD and inpatients of MGM hospital, Kalamboli. All patients from 19 to 45 age groups presenting as menorrhagia, acyclical metropathia, polymenorrhagia, metrorhhagia, oligomenorrhoea, polymenorrhoea and hypomenorrhoea were tested for their thyroid function by $\mathrm{T}_{3}, \mathrm{~T}_{4}$, TSH estimations in their serum. Patients who had clinical signs and symptoms of thyroid disease, were on hormonal treatment, IUCD users, or had bleeding disorders were excluded from the study.

Results: $30 \%$ of patients who were studied had thyroid dysfunction, of which $18 \%$ of patients had subclinical hypothyroidism, $9 \%$ of patients had hypothyroidism and only $3 \%$ of patients had hyperthyroidism. The commonest bleeding abnormalities in subclinical hypothyroid patients were polymenorrhaggia and menorrhaggia. Most of the hyperthyroid cases were oligomenorrhoeic.

Conclusions: Both subclinical hypothyroid and profoundly hypothyroid cases together were the commonest thyroid dysfunction and menorrhagia was their commonest menstrual abnormality. So this study concludes that, biochemical evaluation of thyroid functioning should be made mandatory in all provisionally diagnosed cases of DUB to detect thyroid dysfunction.
\end{abstract}

Keywords: Dysfunctional uterine bleeding, Abnormal uterine bleeding, Thyroid dysfunction, Hypothyroidism, Subclinical hypothyroidism, Hyperthyroidism, Menstrual disorders

\section{INTRODUCTION}

Abnormal uterine bleeding is a common problem amongst women and is associated with an array of symptoms. Frequent complaints include heavier or prolonged menstrual flow with or without pain, passage of clots, weakness, lethargy associated with social embarrassment, significant alteration in lifestyle of individual and sexual compromise. Accurate determination of the prevalence of abnormal uterine bleeding is difficult, however approximately $15 \%$ to $20 \%$ of scheduled office gynaecological visits are for abnormal uterine bleeding.

Abnormal uterine bleeding is a frequent debilitating symptom resulting in unnecessary, incorrect and expensive treatment and invariably ends up in surgical treatment with its attendant risk of morbidity and mortality. As per Te Linde's Operative Gynaecology tenth edition. ${ }^{1} 20 \%$ to $50 \%$ of gynecologic surgical procedures are performed for menstrual dysfunction only. 
Women who experience abnormal uterine bleeding will often present to a physician because of a subsequent negative impact on their daily lives and activities. ${ }^{2,3}$ Abnormal uterine bleeding has been shown to adversely affect mood, energy/vitality, work productivity, social interactions, family life and sexual functioning. ${ }^{4,5}$ The effect abnormal uterine bleeding has on a women's Health Related Quality of Life (HRQL) derives from both the efforts associated with managing menstrual bleeding and the consequences of excessive blood loss, such as fatigue and iron deficiency anaemia. ${ }^{6}$

Abnormality of menstruation is primarily a disorder of hypothalamico-pituitary-ovarian axis either through direct effect or indirectly by their effect on target organ. Endocrinological disturbances other than the reproductive hormones form a small but significant sub-group in the aetiopathogenesis of abnormal uterine bleeding. Amongst the endocrinological causes, after the pituitary, thyroid is probably the most important endocrine organ which exerts a broad range of effects on the development, growth, metabolism and function of virtually every organ system in the human body. ${ }^{7}$

Alterations in production and activity of the thyroid hormones thyroxine $\left(\mathrm{T}_{4}\right)$ and tri-iodothyronine $\left(\mathrm{T}_{3}\right)$ may result in menstrual abnormality. Both hyperthyroidism and hypothyroidism may result in menstrual disturbances.

In hyperthyroidism, amenorrhoea was described as early as 1840 by Von Basedow. ${ }^{8}$ The most common manifestation of hyperthyroidism is oligomenorrhoea and anovulation. It may also cause hypomenorrhoea or menorrhagia.

Hypothyroidism even in subclinical form may result in excessive menstrual bleeding and severe blood loss. The mechanism of menorrhagia in hypothyroidism is incompletely understood. It is postulated that infrequent or absent ovulation leads to deficient secretion of luteinizing hormone which may result in relative estrogen excess thereby causing menorrhagia. There may be episodes of ammenorhoea interspersed with periods of heavy vaginal bleeding also. Various studies have reported that there are changes in cycle length, amount and duration of bleeding associated with thyroid disorders. Sometimes they may also present with infertility, recurrent pregnancy losses and galactorrhoea

Sub-clinical thyroid dysfunction may go unnoticed by unwary clinicians as these patients do not exhibit clinically overt physical symptoms and signs. This may lead to avoidable surgical interference and related complications. With the advent of modern techniques the estimation of various hormones in blood is ${ }^{9}$ possible in rapid and reliable manner. The diagnosis of various endocrine disorders can be easily made and medical treatment can be properly instituted. The results are usually very gratifying as patient is virtually symptom free on adequate treatment.
It has been stated that menorrhagia is more common in hypothyroidism or myxoedema, whilst anovulation or oligomenorrhoea is common in hyperthyroidism. The relative frequency and type of menstrual disorders and the chronology of the onset of reproductive dysfunction with respect to the onset and type of thyroid disorder have not been well defined. It is common practice to investigate for thyroid functions when goiter or clinical symptoms and signs are present.

\section{METHODS}

The present study has been carried out at Obstetrics and Gynaecology outpatient department of MGM Medical College and Hospital; Kalamboli. The study consists of 100 patients coming to OPD with complaints of abnormal uterine bleeding from May 2011 to November 2013.

\section{Sample size}

100 patients

\section{Ethical committee approval}

Permission from ethical committee of MGM Hospital had been taken before starting the proposed study and informed consent from all the subjects recruited in the present study was obtained beforehand.

\section{Inclusion criteria}

All females in 19 to 45 years of age group were included as subjects in proposed study

\section{Exclusion criteria}

1. Patients with previous known thyroid disorder

2. Abortion history within 3 months

3. History of childbirth within 1 year

4. IUCD /OC pill users

5. Patients with known liver disorders or coagulopathy

6. Known cases of cancer of genital organs

7. Known cases of autoimmune disorders

8. Patients not willing to give consent

\section{Procedure}

All the findings were noted in case record form enclosed herewith.

History was taken thoroughly in the form of age and parity status. Detailed menstrual history was obtained 
with respect to onset, duration, amount of bleeding and any other associated menstrual complaints. Any complaint regarding thyroid dysfunction was recorded.

Clinical examination included general examination, systemic examination, routine gynaecological examination and examination of thyroid gland.

Patients with clinical signs and symptoms of thyroid disease were excluded.

All these patients were subjected to routine investigations like haemoglobin, blood counts, urine examination for albumin, sugar, microscopy, bleeding time, clotting time to rule out coagulation defect.

Then all patients were subjected to estimation of serum $\mathrm{T}_{3}, \mathrm{~T}_{4}, \mathrm{TSH}$.

T3 and T4 were estimated with Enzyme Linked ImmuneSorbant Assay (ELISA).

TSH was estimated by ultrasensitive fully automated ELISA assay.

Lab Life ER 2007 Microplate ELISA washer and reader is the instrument used for the present study.

These tests were done in random blood samples as the variation in TSH secretion due to circadian rhythm is small and does not influence the timing of blood sampling.

3 parameters were noted as

1. Serum T3

2. Serum T4

3. Serum TSH

Considering their normal values; patients were categorized into four groups as follows:

1. Euthyroid

2. Subclinical hypothyroid

3. Hypothyroid

4. Hyperthyroid

\section{RESULTS}

Dysfunctional uterine bleeding is one of the most frequently encountered condition in gynaecological practice.

The following tables will analyse:

1. Age

2. Parity

3. Symptomatology of DUB

4. Association with thyroid dysfunction
Total number of patients studied was 100 .

Table 1: Distribution of patients according to age.

\begin{tabular}{|lll|}
\hline $\begin{array}{l}\text { Age group } \\
\text { (years) }\end{array}$ & $\begin{array}{l}\text { No. of } \\
\text { cases }\end{array}$ & Percentage \\
\hline$\leq 20$ & 22 & $22 \%$ \\
\hline $21-30$ & 27 & $27 \%$ \\
\hline $31-40$ & 44 & $44 \%$ \\
\hline $41-45$ & 07 & $07 \%$ \\
\hline Total & 100 & $100 \%$ \\
\hline
\end{tabular}

According to above Table 1, maximum number of patients in this study group belongs to the age group of $31-40$ years i.e. $44 \%$ between age group $41-45$ years $07 \%$ cases were seen.

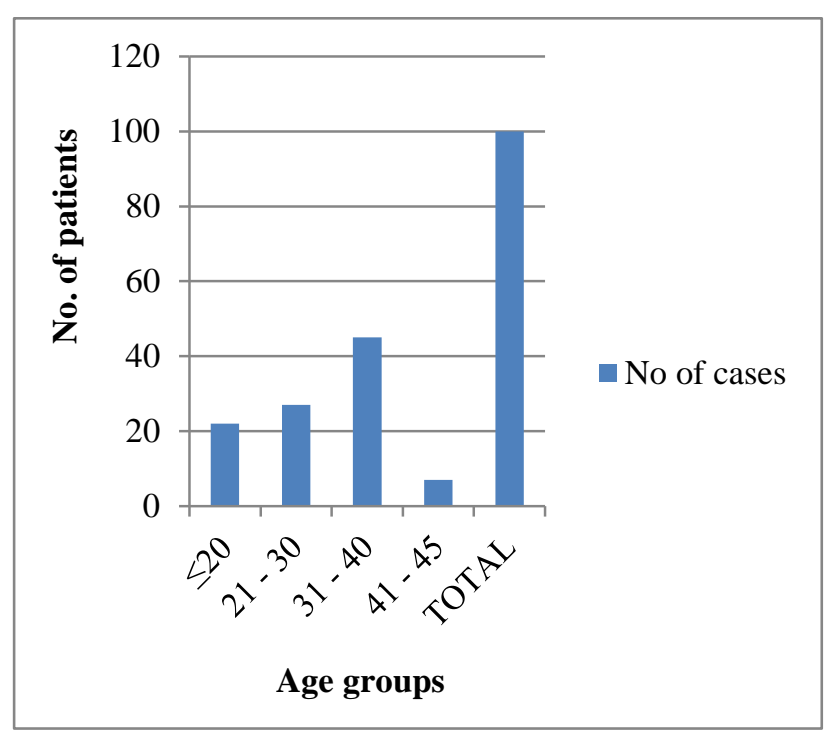

Figure 1: Distribution of patients according to age.

Table 2: Distribution of patients according to parity.

\begin{tabular}{|lll|}
\hline Unmarried & $\begin{array}{l}\text { No. of } \\
\text { patients }\end{array}$ & Percentage \\
\hline 0 & 09 & $19 \%$ \\
\hline 1 & 10 & $09 \%$ \\
\hline 2 & 24 & $10 \%$ \\
\hline 3 & 18 & $18 \%$ \\
\hline 4 & 11 & $11 \%$ \\
\hline 5 & 09 & $09 \%$ \\
\hline & 100 & $100 \%$ \\
\hline
\end{tabular}

The above column shows relationship of DUB with parity. Among 100 cases of DUB, 19 patients were unmarried and nulliparas were 9. 10 patients were para 1 . 11 patients were para 4. 9 patients were para 5. In this study maximum number of patients were para $2(24 \%)$ and minimum number of patients presenting as clinical DUB were of para 5 and nulliparas. 


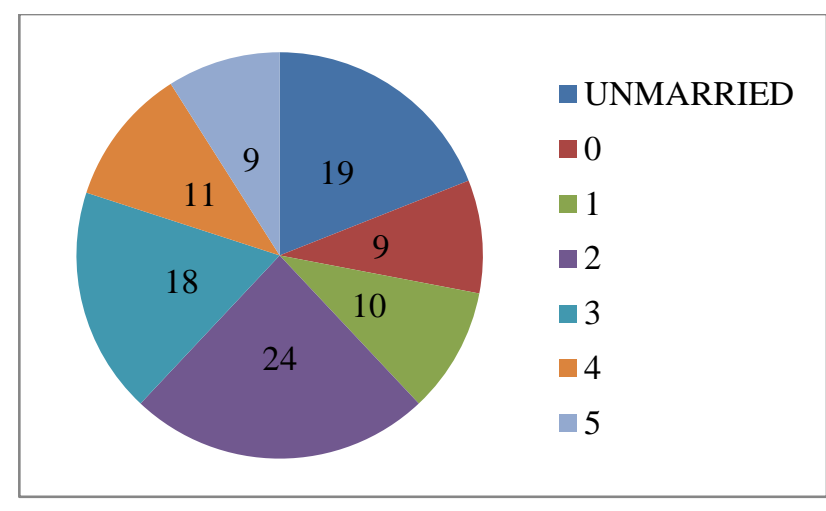

Figure 2: Distribution of patients according to parity.

Table 3: Distribution of patients according to bleeding pattern.

\begin{tabular}{|lll|}
\hline Type of bleeding & $\begin{array}{l}\text { No. of } \\
\text { cases }\end{array}$ & Percentage \\
\hline Acyclical & 18 & $18 \%$ \\
\hline Hypomenorrhoea & 2 & $2 \%$ \\
\hline Menorrhagia & 40 & $40 \%$ \\
\hline Metrorhhagia & 3 & $3 \%$ \\
\hline Oligomenorrhoea & 15 & $15 \%$ \\
\hline Polymenorrhagia & 18 & $18 \%$ \\
\hline Polymenorrhoea & 4 & $4 \%$ \\
\hline Total & 100 & $100 \%$ \\
\hline
\end{tabular}

The above column shows 100 patients who came with the complaint of different bleeding pattern. Commonest was menorrhagia $40 \%$. Among others $18 \%$ presented with acyclical, $15 \%$ with oligomenorrhoea, $18 \%$ had polymenorrhagia, $4 \%$ had polymenorrhoea, $2 \%$ had hypomenorrhoea, 3\% had metrorrhagia. Maximum patients were seen with complaint of menorhhagia, following which polymenorrhagia and acyclical bleeding was seen (18\% each).

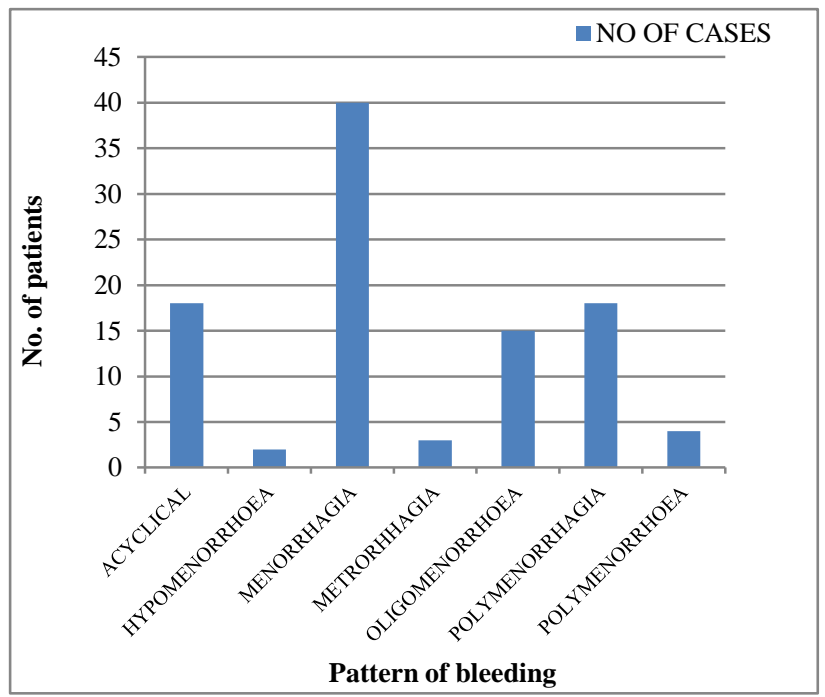

Figure 3: Distribution of patients according to bleeding pattern.

Table 4: Distribution of patients according to age groups and bleeding pattern.

\begin{tabular}{|c|c|c|c|c|c|c|c|c|c|c|c|c|c|c|c|}
\hline \multirow{2}{*}{$\begin{array}{l}\text { Age } \\
\text { (years) } \\
\leq 20\end{array}$} & \multirow{2}{*}{$\begin{array}{l}\text { No. of } \\
\text { cases } \\
22\end{array}$} & \multicolumn{2}{|c|}{ Acyclical } & \multicolumn{2}{|c|}{$\begin{array}{l}\text { Hypo- } \\
\text { menorrhoea }\end{array}$} & \multicolumn{2}{|c|}{ Menorrhagia } & \multicolumn{2}{|c|}{ Metrorrhagia } & \multicolumn{2}{|c|}{$\begin{array}{l}\text { Oligo- } \\
\text { menorrhoea }\end{array}$} & \multicolumn{2}{|c|}{$\begin{array}{l}\text { Poly- } \\
\text { menorrhagia }\end{array}$} & \multicolumn{2}{|c|}{$\begin{array}{l}\text { Poly- } \\
\text { menorrhoea }\end{array}$} \\
\hline & & 8 & $36.3 \%$ & 0 & 0 & 10 & $45.4 \%$ & 1 & $4.5 \%$ & 1 & $4.5 \%$ & 5 & $22.7 \%$ & 0 & 0 \\
\hline $21-\leq 30$ & 27 & 2 & $7.40 \%$ & 2 & $7.40 \%$ & 15 & $55.55 \%$ & 0 & 0 & 6 & $22.22 \%$ & 0 & 0 & 1 & $3.70 \%$ \\
\hline $31-\leq 40$ & 44 & 8 & $18.18 \%$ & 0 & 0 & 12 & $27.27 \%$ & 2 & $4.54 \%$ & 7 & $15.90 \%$ & 10 & $22.72 \%$ & 2 & $4.54 \%$ \\
\hline $41-\leq 45$ & 07 & 0 & 0 & 0 & 0 & 3 & $42.85 \%$ & 0 & 0 & 1 & $14.28 \%$ & 3 & $42.85 \%$ & 1 & $14.28 \%$ \\
\hline & 100 & 18 & & 2 & & 40 & & 3 & & 15 & & 18 & & 4 & \\
\hline
\end{tabular}

Patients with age less than or equal to 20 years, most common bleeding pattern was menorrhagia $(45.4 \%)$.

Followed by acyclical bleeding (36.3\%). Oligomenorhoea was present in $4.5 \%$ of the cases.

Similarly in age group $21-\leq 30$ years and $31-\leq 40$ years, the commonest bleeding pattern was menorrhagia.

Whereas in patients $\geq 41$ years had polymenorrhageoa and menorrhagia are commonest bleeding pattern.

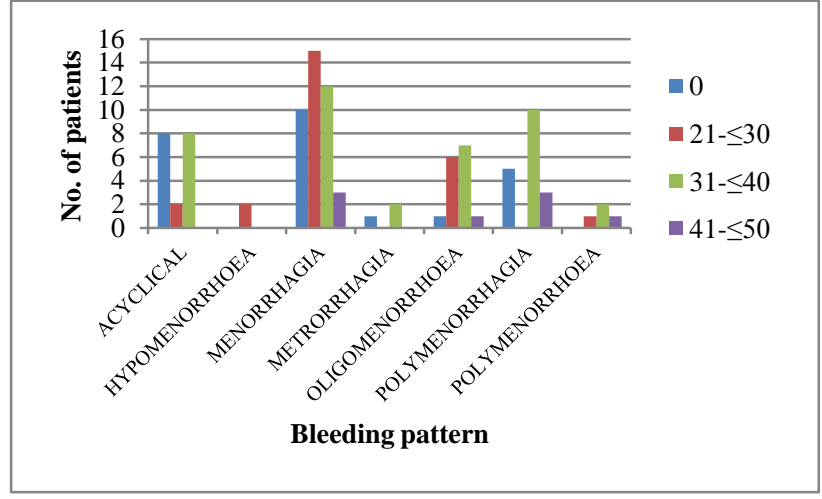

Figure 4: Distribution as per age group and bleeding pattern. 
Table 5: Distribution of patients according to thyroid function.

\begin{tabular}{|lll|}
\hline Thyroid function & $\begin{array}{l}\text { No. of } \\
\text { cases }\end{array}$ & $\begin{array}{l}\text { Percentage } \\
\text { Euthyroid }\end{array}$ \\
\hline Hypothyroid & 9 & $70 \%$ \\
\hline Subclinical hypothyroid & 18 & $9 \%$ \\
\hline Hyperthyroid & 3 & $3 \%$ \\
\hline Total & 100 & $100 \%$ \\
\hline
\end{tabular}

According to this Table 5, maximum number of apparently normal patients with DUB belonged to the category of subclinical hypothyroidism (18\%). Hormonal levels revealing profound hypothyroidism in patients without any symptoms was present in only $9 \%$ of cases. $3 \%$ of cases had hyperthyroidism though they were clinically normal.

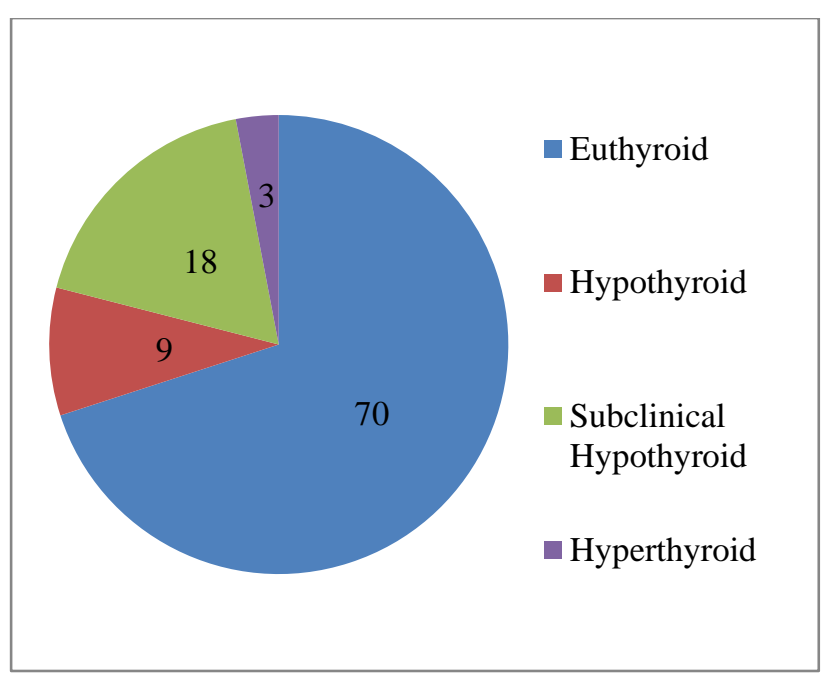

Figure 5: Distribution of patients as per thyroid function.

Table 6: Thyroid dysfunction in different age groups.

\begin{tabular}{|llllllll|}
\hline Age & $\begin{array}{l}\text { No. of } \\
\text { cases }\end{array}$ & Euthyroid & $\begin{array}{l}\text { Hypo } \\
\text { thyroid }\end{array}$ & $\begin{array}{l}\text { Sub } \\
\text { hypothyroid }\end{array}$ & $\begin{array}{l}\text { Hyper } \\
\text { thyroid }\end{array}$ & $\begin{array}{l}\text { Total thyroid } \\
\text { dysfunction } \\
\%\end{array}$ \\
\hline$\leq 20$ & 22 & 15 & 4 & 3 & 0 & 7 & $31.8 \%$ \\
\hline $21-\leq 30$ & 27 & 21 & 2 & 2 & 2 & 6 & $22.2 \%$ \\
\hline $31-\leq 40$ & 44 & 30 & 1 & 12 & 1 & 14 & $31.8 \%$ \\
\hline $41-45$ & 7 & 4 & 2 & 1 & 0 & 3 & $42.8 \%$ \\
\hline Total & 100 & 70 & 9 & 18 & 3 & 30 & \\
\hline
\end{tabular}

This Table 6 shows the relationship between thyroid dysfunction to different age groups. Thyroid dysfunction was commonest in the age group of 41-45 years $(42.8 \%)$. Followed with $31.8 \%$ in $31-40$ and $\leq 20$ years. Thyroid dysfunction was least common in the age group of 21-30 years $(22.2 \%)$. This shows that thyroid dysfunction becomes more common as age advances and in this study it is commonly seen in age group of more than $41-45$ years.

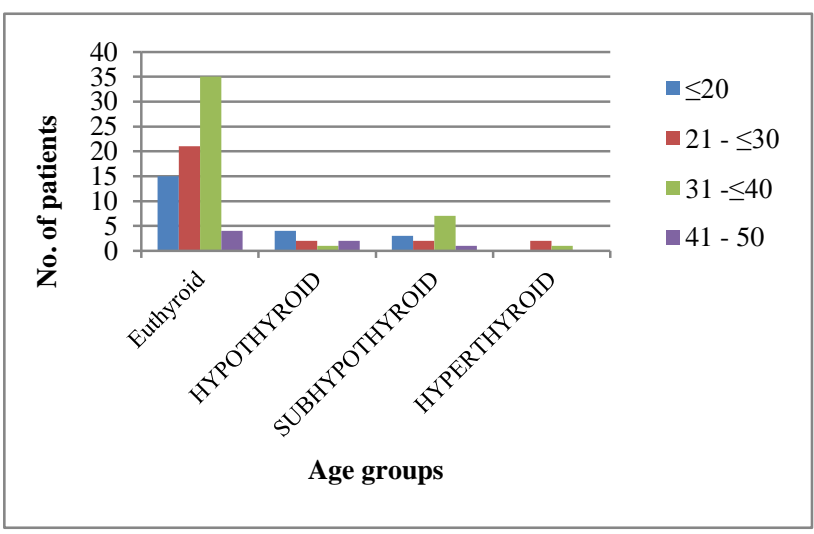

Figure 6: Thyroid dysfunction in different age groups.
Table 7 shows the relationship of hypothyroidism, subclinical hypothyroidism and hyperthyroidism to the different types of clinically diagnosed cases of DUB.

In acyclical metropathia, patients were hypothyroid in $11.1 \%$ of cases and $11.1 \%$ of patients had subclinical hypothyroidism. Whereas in patients with menorrhagia $20 \%$ of patients had hypothyroidism and $12.5 \%$ of patients had subclinical hypothyroidism. Patients with oligomenorrhoea had hyperthyroidism in $13.33 \%$ of patients, hypothyroidism in $60 \%$ of patients and subclinical hypothyroidism in $6.66 \%$. In polymenorrhoea patients $83.3 \%$ of cases had profound hypothyroidism.

So patients who were subclinically hypothyroid were maximally presenting as polymenorrhoea (50\%) and menorrhagia $(12.5 \%)$ and only $6.66 \%$ of patients had oligomenorrhoea. Patients who were profound hypothyroid were predominantly having polymenorrhagia $(83.33 \%)$ and $(60 \%)$ of patients had oligomenorrhoea.

On the other hand patients who were hypothyroid also presented as oligomenorrhoea.

Subclinical hypothyroid patients have polymenorrhoea and menorrhagia as their commonest bleeding pattern. 
Table 7: Bleeding pattern in hypothyroidism and hyperthyroidism.

\begin{tabular}{|llllllllll|}
\hline Type of bleed & $\begin{array}{l}\text { No. of } \\
\text { cases }\end{array}$ & $\begin{array}{l}\text { Eu- } \\
\text { thyroid }\end{array}$ & $\%$ & $\begin{array}{l}\text { Hypo- } \\
\text { thyyroid }\end{array}$ & $\%$ & $\begin{array}{l}\text { Subhypo- } \\
\text { thyroid }\end{array}$ & $\begin{array}{l}\text { Hyper- } \\
\text { thyroid }\end{array}$ & $\%$ \\
\hline Acyclical & 18 & 14 & $77.7 \%$ & 2 & $11.1 \%$ & 2 & $11.1 \%$ & - & - \\
\hline Sub hypomenorrhoea & 2 & 2 & $100 \%$ & - & - & - & - & - & - \\
\hline Menorhhagia & 40 & 27 & $67.5 \%$ & 8 & $20 \%$ & 5 & $12.5 \%$ & - & - \\
\hline Metrorhhagia & 3 & 3 & $100 \%$ & - & - & - & - & - & - \\
\hline Oligomenorrhoea & 15 & 3 & $20 \%$ & 9 & $60 \%$ & 1 & $6.66 \%$ & 2 & $13.33 \%$ \\
\hline Polymenorrhagia & 18 & - & - & 15 & $83.33 \%$ & 2 & $11.11 \%$ & 1 & $5.55 \%$ \\
\hline Polymenorrhoea & 4 & - & - & 2 & $50 \%$ & 2 & $50 \%$ & - & - \\
\hline
\end{tabular}

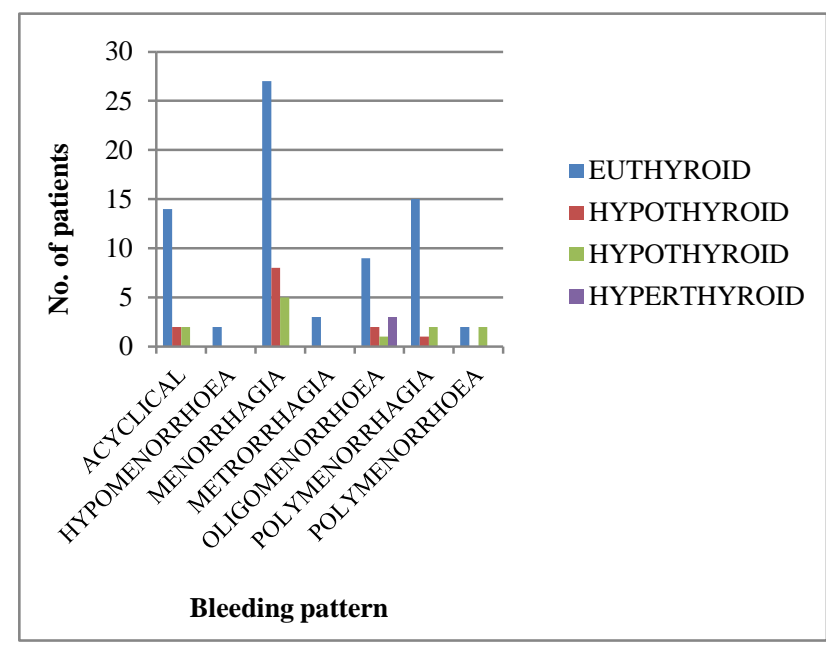

Figure 7: Bleeding patterns in hypothyroidism and hyperthyroidism.

\section{DISCUSSION}

Menorrhagia is a frequent debilitating symptom in gynaecological practice resulting in need for repeated curettage and hysterectomy with its attendant morbidity and mortality. Objective measurements have shown that mean menstrual blood loss in each menstrual cycle is 35 $\mathrm{ml}$ and menstrual blood loss is considered to be excessive when it is more than $80 \mathrm{ml}$ per cycle $\left(90^{\text {th }}\right.$ percentile).

The aetiology of menorrhagia is very diverse. It may be due to systemic conditions like hormonal imbalance (usually hypothyroidism and hyperthyroidism), or local lesions of genital tract like endometrial hyperplasia, pelvic inflammatory disease, endometriosis, benign tumours (leiomyoma, polyps) and malignant tumours (endometrial carcinoma). In more than half of the subjects the cause is usually not apparent.

Thyroid dysfunction is one of the common causes of excessive menstrual blood loss and menstrual irregularities. Menorrhagia has been reported in $32 \%$ of subjects with myxoedema ${ }^{10}$ and in $32.4 \% .^{11}$ It may also lead to anovulation, infertility and recurrent abortion. The onset of hypothyroidism is so insidious that classic clinical manifestation may take months and years to appear. ${ }^{12}$ Furthermore menorrhagia may be the only presenting complain in hypothyroid women. ${ }^{13}$

With the advent of modern hormonal assay techniques precise estimation of thyroid hormones in serum is possible in a rapid and reliable manner. Treatment of hypothyroidism is very satisfying as it usually relieves patient of all the symptoms. Hence in investigating a patient with menorrhagia and/or menstrual irregularities, evaluation of thyroid functional status forms an essential component. Early detection of hypothyroidism in such subjects saves the patient from recurrent curettage and at times hysterectomy.

Among the patients with abnormal thyroid function, significantly higher number of patients had hypothyroidism associated with menorrhagia as an abnormal menstrual pattern $(\mathrm{P} \leq 0.001)$ as per chi square test, which is statistically highly significant.

Similar findings were reported by various authors as given below:

Following Table 8 shows type of menstrual abnormality commonly seen in hypothyroidism as per various authors.

Table 8: Menorrhagia in hypothyroidism. ${ }^{13-15}$

\begin{tabular}{|ll|}
\hline Authors & Menorrhagia \\
\hline Doifode et al. (2001) & $63.3 \%$ \\
\hline Singh et al. (1990) & $44.4 \%$ \\
\hline Wilansky and Bernard (1989) & $100 \%$ \\
\hline Present study (2013) & $32.5 \%$ \\
\hline
\end{tabular}

From this Table 8 , it is seen that incidence of menorrhagia is $40 \%-60 \%$ in cases of hypothyroidism in most of other studies. However, in the present study, the most probable reason for a lower incidence of menorrhagia in hypothyroidism is that patients with clinically apparent thyroid symptomatology were all excluded from beginning of study.

In the present study 100 cases were taken with the complaint of abnormal menstruation. Cases of acyclical metropathia, menorrhagia, hypomenorrhoea, 
metrorrhagia, oligomenorrhoea, polymenorrhoea, polymenorrhagia were all included in this study.

In the study by Doifode et al., 213 cases of clinically diagnosed DUB were taken. Patients with oligomenorrhoea, hypomenorrhoea and polymenorrhoea were excluded in author's study. In both the studies commonest complaint was menorrhagia. ${ }^{14}$

In the above study 60 patients out of 213 patients showed their thyroid dysfunction as hypothyroidism, either subclinical or profound. Author's study had no case of hyperthyroidism. ${ }^{14}$

Table 9: Hypothyroidism in different bleeding patterns. $^{14}$

\begin{tabular}{|llll|}
\hline \multicolumn{3}{c}{$\begin{array}{l}\text { No. of pts. } \\
\text { presenting with } \\
\text { Study }\end{array}$} & \\
& $\begin{array}{l}\text { menorrhagia, } \\
\text { polymenorrhagia, } \\
\text { metropathia, } \\
\text { metrorrhagia }\end{array}$ & $\begin{array}{l}\text { Patients who had } \\
\text { hypothyroidism }\end{array}$ \\
\hline Present study & 79 & 34 & $43.03 \%$ \\
\hline $\begin{array}{l}\text { Doifode et al. } \\
\text { (2001) JOGI }\end{array}$ & 213 & 60 & $28.17 \%$ \\
\hline
\end{tabular}

In the author's study patients with clinical signs and symptoms of hypothyroidism were also included, whereas in the present study patients with clinically diagnosed DUB with signs and symptoms of hypothyroidism were excluded. ${ }^{14}$

In the present study hypothyroidism was the commonest thyroid dysfunction seen in patient with all the seven different types of menstrual disturbances. In the following table the commonest menstrual disturbances in hypothyroidism is shown in the present study and in the author's study.

Table 10: Menstrual pattern in hypothyroid patients. $^{14}$

\begin{tabular}{|lllll|}
\hline $\begin{array}{l}\text { Bleeding pattern } \\
\text { Acyclical } \\
\text { metropathia }\end{array}$ & 4 & $8.32 \%$ & 4 & $6.66 \%$ \\
\hline Menorrhagia & 13 & $27.04 \%$ & 38 & $63.33 \%$ \\
\hline Polymenorrhagia & 17 & $35.36 \%$ & 14 & $23.33 \%$ \\
\hline Metrorrhagia & - & - & 4 & $6.66 \%$ \\
\hline Oligomenorrhoea & 10 & $20.8 \%$ & - & - \\
\hline Polymenorrhoea & 4 & $8.32 \%$ & - & - \\
\hline Hypomenorrhoea & - & - & - & - \\
\hline $\begin{array}{l}\text { Total hypothyroid } \\
\text { patients }\end{array}$ & 48 & - & 60 & - \\
\hline
\end{tabular}

The type of menstrual abnormality commonly seen in hypothyroidism was menorrhagia $(63.33 \%)$ in author's study. Polymenorrhagia was the commonest menstrual abnormality in the present study (35.36\%).
Polymenorrhagia was the next common menstrual abnormality $23.33 \%$ in the author's study. Author's study had excluded cases of polymenorrhoea. However, in the present study menorrhagia and oligomenorrhoea were together common menstrual abnormality in $27.04 \%$ and $20.8 \%$ of hypothyroid cases.

In the present study, hyperthyroidism was seen only in cases of oligomenorrhoea $(66.6 \%)$ and polymenorrhagia $(33.3 \%)$.

Reversely, oligomenorrhoea was most commonly observed in patients suffering of hypothyroidism (60\%) and subsequently euthyroidism (20\%) and very less in hyperthyroidism $(13.33 \%)$.

Table 11: Oligomenorrhoea in hyperthyroidism. ${ }^{15}$

\begin{tabular}{|ll|}
\hline Study & Oligomenorrhoeal \\
\hline Singh et al. (1990) & $64 \%$ \\
\hline Present study & $66.6 \%$ \\
\hline
\end{tabular}

Table 12: Age pattern in dub with thyroid dysfunction. $^{14}$

\begin{tabular}{|c|c|c|c|c|}
\hline \multirow[b]{2}{*}{$\begin{array}{l}\text { Age } \\
\text { (years) }\end{array}$} & \multicolumn{2}{|l|}{ Present study } & \multicolumn{2}{|c|}{ Author's study } \\
\hline & $\begin{array}{l}\text { No. of pts. } \\
\text { with } \\
\text { thyroid } \\
\text { dysfunction }\end{array}$ & $\%$ & $\begin{array}{l}\text { No. of pts. } \\
\text { with } \\
\text { thyroid } \\
\text { dysfunction }\end{array}$ & $\%$ \\
\hline$<20$ & 7 & $31.8 \%$ & 7 & $11.67 \%$ \\
\hline $21-30$ & 6 & $22.2 \%$ & 10 & $16.67 \%$ \\
\hline $31-40$ & 14 & $31.8 \%$ & 29 & $48.33 \%$ \\
\hline$>40$ & 3 & $42.8 \%$ & 14 & $23.33 \%$ \\
\hline Total pts. & 30 & & 60 & \\
\hline
\end{tabular}

This Table 12 compares the relationship between age pattern with thyroid dysfunction among patients with DUB in the present study and in author's study. From this table it is noted that thyroid dysfunction is commonest in the age group of more than 40 years, both in the present study as well as in the author's study.

Thus, the present study was aimed at detecting and evaluating thyroid dysfunction in patients with provisional diagnosis of DUB and positive cases were referred to physician for further management.

Our study concludes that thyroid disorder should be considered as an important aetiological factor for menstrual abnormality.

Thus biochemical evaluation $\mathrm{T}_{3}, \mathrm{~T}_{4}$ and TSH estimations should be made mandatory in DUB cases to detect profound and subclinical thyroid dysfunction.

These patients with thyroid dysfunction, if given medical treatment, it is possible to avoid unnecessary hormonal treatment and costly surgical interventions. 
Funding: No funding sources

Conflict of interest: None declared

Ethical approval: The study was approved by the ethics committee of MGM Hospital

\section{REFERENCES}

1. John Thompson, Jeferey Warshaw. Hysterectomy. In: John Rock, eds. Te Linde's Operative Gynecology. 8th ed. Philadelphia: Lippincott Williams and Wilkins Company; 1997: 771-854.

2. El-Hemaidi I, Gharaibeh A, Shehata H. Menorrhagia and bleeding disorders. Curr Opin Obst Gynaecol. 2007;19:513-20.

3. Santer M, Wyke S, Warner P. What aspects of periods are most bothersome for women reporting heavy menstrual bleeding? Community survey and qualitative study. BMC Women's Health. 2007;1:78.

4. Shapley M, Jordan K, Croft PR. Why women consult with increased vaginal bleeding: a case control study. Br J Genet Pract. 2002;52:108-13.

5. Winkler UH. The effect of tranexaemic acid on the quality of life of women with heavy menstrual bleeding. Euro J Obstet Gynaecol Reprod Biol. 2001;99:238-43.

6. Liu Z, Doan QV, Blumenthal P, Dubois RW. A systematic review evaluating health related quality of life, work impairment and health care costs and its utilization in abnormal uterine bleeding. Value Health. 2007;10:183-94.

7. David Olive, Steven Palter. Reproductive physiology. In: Jonathan S. Berek, eds. Berek and Novak's Gynaecology. 14th ed. Philadelphia:
Lippincott Williams and Wilkins Company; 2002: 161-186.

8. Steiner RA, Fink D. Abnormal menstrual bleeding. Schweiz Rundsch Med Prax. 2002;91:1967-74.

9. Akande E, Hockaday T. Plasma luteinizing hormone levels in women with thyrotoxicosis. J Endocrinol. 1972;53:173.

10. Means JH. The thyroid and its diseases. In: Means JH, eds. A Book. 2nd ed. Philadelphia: J.B. Lippincott Co.; 1948: 571.

11. Wilansky DL, Greisman B. Early hypothyroidism in patients of menorrhagia. Am J Obstet Gynaecol. 1989;3:673-7.

12. Wg Cdr S. Sampath, Col P. Singh, Somani BL, Col MM. Arora, Lt Col HS. Batra, Lt Col AK. Harith, et al. Study of clinicobiochemical spectrum of hypothyroidism. Med $\mathrm{J}$ Armed Forces India. 2007;63(3):233-6.

13. Lewis Braverman, David Cooper. The thyroid. In: Lewis Braverman, David Cooper, eds. Ingbar and Werner's Fundamental and Clinical Text. 10th ed. Philadelphia: Lippincott Williams and Wilkins Company. 2012: 792.

14. Doifode CD, Fernandes K. Study of thyroid dysfunction in patients with dysfunctional uterine bleeding. J Obstet Gynecol India. 2001;51:93-5.

15. Lakshmi Singh, Agarwal CG, Choudhary SR, Mehra $\mathrm{P}$, Rajan Khare. Thyroid profile in infertile woman. J Obstet Gynecol India. 1990;40:248.

DOI: $10.18203 / 2320-1770$. ijrcog20150077

Cite this article as: Deshmukh PY, Boricha BG, Pandey A. The association of thyroid disorders with abnormal uterine bleeding. Int J Reprod Contracept Obstet Gynecol 2015;4:701-8. 